\title{
Character Education Models to Develop Anti- Plagiarism Behavior among Students in the Faculty of Engineering
}

\author{
Muhammad Rais \\ Faculty of Engineering \\ Universitas Negeri Makassar \\ Makassar, Indonesia
}

\author{
Farida Aryani \\ Faculty of Education \\ Universitas Negeri Makassar \\ Makassar, Indonesia
}

\begin{abstract}
This study aims at examining the effect of character education models to avoid students' plagiarism behaviour. The authors used a quantitative research with the pre-experimental design. The study involved fifty students from the Faculty of Engineering at the Universitas Negeri Makassar selected by random sampling technique. Moreover, the authors conducted Focus Group Discussion (FGD) as a treatment to support this study. Quantitative data were analysed using a $t$-test to find out the mean scores between pretest and posttest. The results showed an improvement in the average score of avoiding plagiarism before and after the treatment through improvement in character education. Focus group discussion results also revealed that students were very enthusiastic about character education model that was trained. The participants were considered to be helped regarding avoiding plagiarism. Therefore, the students feel more confident in doing a writing assignment. The authors recommend implementing character education model officially for a first-year student at higher education. Further research is expected to involve a large-scale population to investigate the effectiveness effort in avoiding plagiarism behaviour.
\end{abstract}

Keywords-character education model; self-efficacy; plagiarism behaviour

\section{INTRODUCTION}

The complexity of the school system especially in the Indonesia is based on the sustainable development concept to provide the community knowledge and motivation to improve their value of the life of their next generation. Moreover, the information technology in relations with the education system creates more people are aware of gaining more knowledge, and more information. Therefore, the need of information technology is increasingly likely to provide more details to all community.

The advancement of informatics makes students easier to plagiarise other [1]-[3]. Many students feel free in doing plagiarism as an academic dishonesty by using other people works without quoting, citing, and referencing [4]. Students will lose their moral and character if plagiarism continues to happen. Therefore, it is needed immediate treatment is required to improve student academic integrity.
From earlier observation, students might have some reasons doing plagiarism. Some students might argue that they do plagiarism because they are lack of knowledge on plagiarism limitation, high pressure on publication, and poor character education both at home and at the campus. Other students also might argue that they are involved in plagiarism because they are lack of motivation, need of peer support, and a shortage of self-efficacy to their own academic writing proficiency. Students who have low academic writing skill but high achievement expectation could have a significant risk to be engaged in plagiarism.

Students who are involved in plagiarism due to low selfefficacy [5], [6]. Self-efficacy includes the effect of individual evaluation of the capabilities and potential as the basis of behaviour dealing with the tasks. Also, self-efficacy involves the consequence of the social cognitive process of beliefs and expectations as well as the decision on the individual's ability to act to obtain maximum outcomes. Błachnio and Weremko (2012) argued that a person with low self-confidence tend to cheat other works. Barzegar and Khezri (2012) studied that a person with low self-efficacy is more likely to be involved in plagiarism behaviour. It can be synthesised that self-efficacy determines how a student thinks, behaves and motivates her/himself in their learning. In other words, the success of a student on self-efficacy is attributed to her/his learning skills. Anderson, Krathwohl and Bloom (2001) explained that learning is a process of managing meta-cognitive knowledge to use appropriate learning strategies.

The authors proposed a character education strategy to prepare students with academic integrity. Character education is a preventive approach given to young students to encourage character values to students, which includes knowledge, awareness, and willingness to implement the values of antiplagiarism character [10]. The strategy used to develop the teaching of these characters is based on the findings by Martens (1996) proposed a strategy of effective character education, which is in particular strategy. The authors conducted three phases of developing the students' character, identification of value, the involvement of value through teaching, and provide an opportunity for students to implement these values including the knowledge about 
plagiarism, self-efficacy, and learning skills as anti-plagiarism aspects.

\section{RESEARCH METHOD}

This study is pre-experimental design with only one experimental group without a control group that the effect of the intervention compared before and after the intervention in the experimental group [12]. Fifty students $(n=50)$ from the Faculty of Engineering at the Universitas Negeri Makassar participated in this study. The authors developed the research instrument used in this research. This scale refers to a theory developed by Lickona (2009) and Bandura (1994). Three aspects identified in this study, they are lack of knowledge of plagiarism behaviour, low self-efficacy, and lack of learning skills. To support the results of the study, the authors made a Focus Group Discussion (FGD). The data were analysed using the mean score to find out the mean score between pretest and post test of each aspect identified. The authors also used a ttest to determine the significant difference between pre test and post test.

\section{RESULTS}

This section deals with the data analysis results using mean score and $t$-test. Mean score as in Fig. 1 showed the difference of each aspect consist of knowledge about plagiarism, selfefficacy, and learning skill between pretest and posttest. The $t$ test as in Table 1 demonstrated the significant difference between pretest and post test of this study. The differences of anti-plagiarism's mean score between pretest and posttest are as follows.

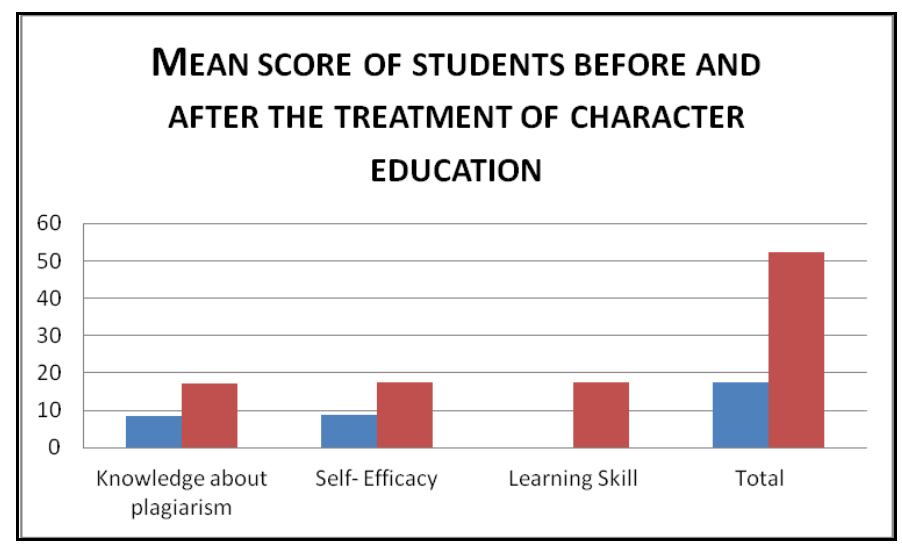

Fig.1. Mean Score of Student Before and After Treatment

Mean score of knowledge plagiarism before treatment was 8.56 and 17.3 after the treatment. The mean score of selfefficacy before treatment was 8.88 and reached 17.62 after the treatment. The mean score of learning skills before the intervention that was 8.58 could reach 17.5 scores after the treatment. The mean score of anti-plagiarism behaviour was 26.02 before treatment and increased by 52.46 after the respondents were trained. The improvement of all categories shows that there is a significant impact of the anti plagiarism model can improve the character of the students. The anti plagiarism model also shows that the improvement is two times or two folds mean score, this indicates that there is a significant impact for students to write more paper without any plagiarism issues.

TABLE I. THE SIGNIFICANCE DIFFERENCE T-TEST SCORE OF ANTIPLAGIARISM BEHAVIOUR AMONG STUDENT BEFORE AND AFTER THE CHARACTER EDUCATION

\begin{tabular}{|l|l|l|l|l|l|l|}
\hline \multicolumn{7}{|c|}{ One-Sample Test } \\
\cline { 2 - 7 } & \multicolumn{1}{|c|}{ Test score $=0$} \\
\hline & T & Df & $\begin{array}{l}\text { Sig. (2- } \\
\text { tailed) }\end{array}$ & $\begin{array}{l}\text { Mean } \\
\text { Difference }\end{array}$ & \multicolumn{2}{|l|}{$\begin{array}{l}\text { 95\% Confidence } \\
\text { Interval of the } \\
\text { Difference }\end{array}$} \\
\cline { 3 - 6 } & & & & Lower & Upper \\
\hline $\begin{array}{l}\text { Pretest } \\
\text { Plagiarism } \\
\text { score }\end{array}$ & 76.6 & 49 & .001 & 26 & 25.3 & 26.7 \\
\hline $\begin{array}{l}\text { Posttest } \\
\text { Plagiarism } \\
\text { score }\end{array}$ & 184.3 & 49 & .001 & 52 & 51.9 & 53.0 \\
\hline
\end{tabular}

The $t$-test results as in Table 1 showed that anti-plagiarism behavior before treatment was $(t=76562, \mathrm{p}=0.000<0.05) \mathrm{df}$ $49(\mathrm{n}-1,50-1)$ and reached $(\mathrm{t}=184.340 \mathrm{p}=0.000>0.05)$ on $\mathrm{df}$ 49 (n-1. 50-1) after character education model implemented. Thus, $\mathrm{t}$ count before treatment and after treatment $=76.6=$ $184.340>\mathrm{t}$ table $=2.021$. This study showed that there was a significant increase awareness of students against plagiarism after implementing the character education model as an effort of anti-plagiarism behavior among student.

\section{DISCUSSION}

The result of this study showed that character education models exposed the significant increase the anti-plagiarism behaviour among students of Faculty of Engineering, Universitas Negeri Makassar. After the treatment, the authors focused on knowledge about plagiarism, self-efficacy, and learning skills as identified aspects to measure the antiplagiarism behaviour. The detail of these three elements is presented as follows.

\section{A. Knowledge about plagiarism}

Student awareness of the plagiarism behaviour before training of character education was in the low mean score and increased significantly after the treatment. The Focus Group Discussion (FGD) and the results of this study showed that lecturers never provide students with the skills to write scientific papers. This condition leads students' lack of technique of quoting, either from the Internet or other sources [1]. Moreover, most of the lecturers assign students to write papers, but they provide lack of feedback. Therefore the model for anti plagiarism is needed to promote in the other school to give opportunity for all students to write and promote their visions

\section{B. Self-efficacy}

The results of this study showed the significant increase of self-efficacy between before and after educating the students about character education. This is regarded as an uncertainty sense of a student own abilities to do the assignment. Bandura (1994) explains that self-efficacy is an individual evaluation of the capacity to organise and implement actions to achieve specific performance. The higher the students' self-efficacy 
contributes to the better of the learning performance to avoid plagiarism behaviour [8]. The self-efficacy also gave students motivation to write more because they found that writing a paper become easy than before

\section{Learning Skills}

The results of this study indicated that learning skills of most students were in the low level before being provided with a character education model. This circumstance considered by lack of understanding of academic writing. Anderson, Krathwohl and Bloom (2001) explain that learning is a process of managing metacognitive knowledge as the ability to use appropriate learning strategies. Good learning determines how the quality learning process is perceived and experienced by learners. This implies that the students who are involved in plagiarism are those who are result-oriented. This can lead students to shortcut way by plagiarising other works. Therefore, students need a technique or ways of avoiding this misconduct behaviour [13].

\section{CONCLUSION}

This study showed that education character models significantly improved anti plagiarism behaviour among students of Faculty of Engineering, Universitas Negeri Makassar. The character education model should be implemented as a model to welcome new students as an official activity organised by the university. Furthermore, it is recommended that character education models can be tested in a larger population with a well-designed and validated questionnaire to examine the effectiveness in improving antiplagiarism behaviour among students [14]. The students' enthusiasm on the character education models reflects the significance of this model to be implemented in regular academic activities. This model is expected to build academic integrity by providing students skills to write scientific papers and to learn effectively.

\section{ACKNOWLEDGMENT}

Acknowledgements addressed to the Directorate General of Higher Education for funding this second year of competitive research grants, a period of 2016. This study is projected to produce a model of character education.

\section{REFERENCES}

[1] L. J. P. Davies and R. M. Howard, "Plagiarism and the Internet: Fears, Facts, and Pedagogies," Handb. Acad. Integr., p. 591, 2016.

[2] N. Hussein, S. D. Rusdi, and S. S. Mohamad, "Academic Dishonesty Among Business Students: A Descriptive Study of Plagiarism Behavior," in 7th International Conference on University Learning and Teaching (InCULT 2014) Proceedings, Singapore: Springer Singapore, 2016, pp. 639-648.

[3] D. Klein, "Why learners choose plagiarism: A review of literature," Interdiscip. J. E-Learning Learn. Objects, vol. 7, no. 1, pp. 97-110, 2011.

[4] S. F. Karabag and C. Berggren, "Retraction, dishonesty and plagiarism: analysis of a crucial issue for academic publishing, and the inadequate responses from leading journals in economics and management disciplines," J. Appl. Econ. Bus. Res., vol. 2, no. 3, pp. 172-183, 2012.

[5] A. Bandura, Self-efficacy. Wiley Online Library, 1994.

[6] D. D. Prior, J. Mazanov, D. Meacheam, G. Heaslip, and J. Hanson, "Attitude, digital literacy and self efficacy: Flow-on effects for online learning behavior," Internet High. Educ., vol. 29, pp. 91-97, Apr. 2016.

[7] A. Błachnio and M. Weremko, "Academic Cheating is Contagious: the Influence of the Presence of Others on Honesty. a Study Report," Int. J. Appl. Psychol., vol. 1, no. 1, pp. 14-19, Aug. 2012.

[8] K. Barzegar and H. Khezri, "Predicting academic cheating among the fifth grade students: The role of self-efficacy and academic selfhandicapping," J. Life Sci. Biomed., vol. 2, no. 1, pp. 1-6, 2012.

[9] L. W. Anderson, D. R. Krathwohl, and B. S. Bloom, A taxonomy for learning, teaching, and assessing: A revision of Bloom's taxonomy of educational objectives. Allyn \& Bacon, 2001.

[10] T. Lickona, Educating for character: How our schools can teach respect and responsibility. Bantam, 2009.

[11] R. Martens, Successful coaching. Human Kinetics, 1996.

[12] B. W. Tuckman and B. E. Harper, Conducting Educational Research. Rowman \& Littlefield Publishers, 2012.

[13] A. Chowdhry, "Ways to Avoid and Dodge Plagiarism in Scientific Writing? Personal Experience," Account. Res., vol. 23, no. 3, pp. 195197, May 2016

[14] A. A. Patak, A. N. Hamimah, T. Rohaya, E. Akib, and A. G. M. Najib, "Design and validation of plagiarism practice survey using Rasch Measurement Model," in Interdisciplinary Behavior and Social Sciences, 2015, pp. 405-408. 